\title{
DIE HUIDIGE STAND VAN DIE ONDERSOEK TEN OPSIGTE VAN DIE EVANGELIUM VERITATIS.
}

Die Vonds.

Die afgelope vyf-tal jare was vir die ontwikkeling van die Bybelwetenskap en die ondersoek van die vroegste geskiedenis van die Christelike Kerk van buitengewone belang. Teenoor vroeëre ontdekkinge van afsonderlike manuskripte en boeke, in kloosterbiblioteke en privaat versamelinge, val dié sedert 1946 op deur die feit dat hele antieke biblioteke in mindere of meerdere behoue staat, na 2000 jare aan die lig kom. Vroeëre ontdekkinge het, relatief gesproke, nie juis iets totaal nuuts gebaar nie. Hoe belangrik byvoorbeeld ookal die ontdekkinge van die Codex Sinaiticus en die Codex Vaticanus was, en onlangs nog die Chester Beatty Papyri, dit het per slot nie meer gelewer nie as ' $n$ helderder, bevredigender beligting van materiaal waaroor ons reeds beskik het.

92 
Van die biblioteke van die Markusgrot en nou van Nag-Hammadi, is die onhoud nog onvolledig bewerk en grotendeels nog nie gepubliseer nie; tog weet ons reeds dat hier onvoorsien en onverhoop buitengewoon gewigtige brokke nuwe kennis aan die wetenskap blootgelê is. Laat ons so sê: vroeëre ontdekkinge het ons bestaande kennis gepresiseer; die reeks ontdekkinge vanaf 1946 het dit verwyd, die horisonte daarvan uitgestoot. Die inhoud van die Markusgrot en nou, laastens, die ontdekking van die gnostiese biblioteek te Nag-Hammadi gee gestalte en vorm aan groothede waarvan ons vroeër nie veel meer as die naam geken het nie. Hierdie biblioteek uit die omgewing van Luxor werp lig op die kristalisering van ons Nuwe Testament in sy huidige vorm en gee ons 'n lewendige beeld van die stryd van die vroeë Christene om die oorgelewerde leer van Christus en die Apostels te handhaaf teen die subtiele spekulasies van die gnostiek.

Die ondersoek van die materiaal wat by Nag-Hammadi ontdek is, staan nog maar op die drumpel. Wetenskaplikes en technici sal tientalle jare van toegewyde studie nodig hê om die volle rykdom en draagwydte daarvan bloot te lê, maar die toewyding waarmee die werk tot dusver voortgesit is, hou n' sekere belofte vir die toekoms in.

Ongeveer 80 myl ten Noorde van Luxor, aan die westelike oewer van die Nyl, teenoor die geskiedkundige Chenoboskion waar Pachomius in die vierde eeu n.C. sy eerste kloosters gestig het, lê die dorpie NagHammadi. Die hoë kalkformasies daar bevat grafte vanaf die sesde dinastie van die Farao's tot in die Grieks-romeinse tyd. In 1945 het landwerkers in hierdie ou begraafplaas 'n erdekan opgegraaf, dit stukkend geslaan en 'n hoeveelheid manuskripte tevoorskyn gehaal. Gedeelte daarvan het hulle verbrand en die res het klompies-klompies in die handel gekom. Gedeelte het tereg gekom in die Kairo-museum, 'n tweede groep van 11 manuskripte is tussen 1946 en 1949 aangekoop deur 'n privaatversamelaar wat dit, soos dit hom ter hand gekom het, aan die ondersoeker Doresse laat sien het. Maar in 1949 maak hy dit oor aan die Kairo-museum waar dit met die tevore reeds aangekoopte gedeelte nou nog berus en voorlopig vir die ondersoeker ontoeganklik sal bly weens die beleid van die huidige Egiptiese reg?ring. Die stukke is ret bekend uit die voorlopige opmerkinge daaroor deur die ondersoekers DoResse en Puech.

'n Derde groep is egter in 1946 aangekoop deur 'n Belgiese handelaar in oudhede met die naam van EID. Hy het dit na Amerika geneem en dit agtereenvolgens aangebied aan die Universiteit van Michigan en die Bollingen Stigting te New York - eers vir $£ 2,000$ later vir $£ 6,000$. Die Amerikane het hulle nie daarvoor geïnteresseer nie. Kort daarop het die handelaar, inmiddels na Europa teruggekeer, gesterf. Tot op die stadium het niemand nog met sekerheid geweet wat die codices presies bevat nie. Alleen o.g.v. 'n verklaring van 
DORESSE is vermoed dat hulle in verband kon staan met die vroegchristelike gnostiek. Die gerug wou verder dat een van hulle die naam, Evangelie van die Waarheid gedra het. Geleerdes het vermoed dat dit dieselfde geskrif is as waarna Irenaeus en sy Adversus Haereses teen die jaar 180 n.C. verwys het.

$\mathrm{Na}$ die dood van die laaste eienaar het tydelik alle spore van versameling verdwyn. In 1950 is egter verneem dat dit in Brussel is. Die berig was waar Prof. G. Quispel, hoogleraar in die ouchristelike Lettere aan die Rijksuniversiteit te Utrecht, wat op daardie stadium al geruime tyd besig was met ondersoek oor die Valentiniane, een van die oudste christelik-gnostiese sektes, kom die eer toe dat hy, naas PuEch en Doresse, dadelik die moontlikhede van die versameling ingesien het en pogings in die werk gestel het om dit op te spoor. Deur tussenkoms van Prof. J. C. Jung, die bekende psigoloog van Zürich, het die Bolling Stigting tog besluit om die manuskripte van die nuwe eienaar te koop. Quispel is gevra om vóór die sluiting van die transaksie vas te stel of die geskrifte wel waarde het. Die voorlopige lees van een bladsy was voldoende om hom te oortuig dat dit klink klaar valentiniaans was. In 1952 is die koop deurgevoer egter onder die voorwaarde van die kant van die verkoper dat dit nie voor November 1953 bekend gemaak sou word nie. Ondertussen het die ondersoek van die materiaal darem voortgegaan sodat 'n gevorderde, sy dit ook voorlopige bewerking reeds in November 1953 in die openbare pers kon verskyn. Vier geleerdes in die besonder is met die ondersoek belas; Prof. M. Malinine van Parys, 'n ervare copticus is belas met die rekonstruksie van die teks; PROF. W. C. van UNNIK van die Rijksuniversiteit te Utrecht bepaal die waarde van die ontdekking vir die Nuwe Testament. Profr. Quispel en Puech, laasgenoemde van die College de France, berei die uitgawe van die teks met vertaling en aantekeninge vooi.

\section{StaAt EN Inhoud VAN diE Vonds.}

Die oorspronklike blootlegging het, volgens DoResse en Puech, dertien in mindere of meerdere mate geskonde codices bevat. Dit het 48 werke van tesame ongeveer 1,000 bladsye behels. Hiervan was 46 voorheen inhoudelik of slegs by name bekend. Die gedeelte wat deur die volharding van QuISPEL en die bemiddeling van JuNG toeganklik geword het en ter ere van laasgenoemde bekend staan as Codex-Jung, het al dadelik deur sy vorm hom onderskei van die res - dit is langer en nouer en is beskryf in sub-achmimies, die koptiese dialek van MiddeEgipte, in die taal dus van die plek waar dit gevind is. Te oordele aan die tipe van skrif waarin dit opgestel is, dateer dit uit die derde of vierde eeu n.C. Soos die ander werke dra dit die kenmerke van 'n 
vertaalwerk uit die Grieks. Cod. Jung bevat 100 bladsye maar moes oorspronklik 138 bladsye beslaan het; veral teen die einde is groot stukke verlore. Die behoue gedeelte behels :

1. 'n Apokriewe kunsbrief onder die naam van Jakobus, die broer van die Here. Dit weerspieël 'n esoteriese leer.

2. Die Evangelie van die Waarheid, sonder opgawe van outeursnaam en ewe-eens esoteries-apokalipties van aard. Dit bestaan uit 27 bladsye. Uit die laaste kwart is vier bladsye verlore.

3. 'n Mities-teologiese opstel oor die Drie Nature. Hierdie werk moes oorspronklik omvangrik gewees het, maar die eerste vier bladsye en 41 tussen-in is verlore.

4. Die Brief aan Rheginos, 'n kunsbrief oor die opstanding, bestaande uit 6 bladsye. Die slot is verlòre.

5. Twee gehawende bladsye van 'n Gebed van die Apostel.

Al hierdie werke is duidelik gnosties van aard, maar dis veral op die tweede van hierdie geskrifte, namelik die Evangelie van die Waarheid dat die ondersoek hom tot dusver hoofsaaklik gekonsentreer het en begryplik ook. Nie alleen uitwendig is dit die volledigste van die versameling nie, maar inhoudelik is dit by verre die belangrikste. Die ontdekking daarvan bring eerstens einde aan 'n tergende probleem: Die bestaan van 'n gnostiese Evangelie van die Waarheid is namelik al sewentien eeue bekend. Irenaeus in sy reeds genoemde Adversus Haereses III.11.9 verklaar: „Die aanhangers van VALENTINus bring sonder enige skaamtegevoel hul eie geskrifte navore en beroem hulle daarop dat hulle meer het as wat die Evangelies self bevat. Trouens so ver het hulle in vermetelheid gevorder dat hulle een van hul onlangs vervaardigde geskrifte Die Evangelie van die $W$ aarheid noem, hoewel dit in geen opsig ooreenkom met die Evangelies van die Apostels nie, sodat selfs nie die Evangelies aan hul laster ontkom nie". Want as dit wat hulle voorhou as die Evangelie van die Waarheid dit in feite is terwyl dit egter verskil van die Evangelies wat deur die Apostels aan ons oorgelewer is, kan die wat dit wil . . voortaan leer dat dit wat deur die Apostels oorgelewer is, nie die Ware Evangelie is nie". IRENAEus deel egter niks oor die inhoud mee nie behalwe sy oordeel dat dit in geen opsig ooreenkom met die Evangelies van die Apostels nie en dat dit daarom niks anders as 'n stuk laster teen die egte Evangelies is nie.

Weens die gemis aan ' $n$ verwysing na die inhoud, is die gevolgtrekking gemaak dat IrenaEus die valentiniaanse Evangelie van die Waarheid nooit self gesien het nie maar put uit 'n mededeling daaroor.

Die enigste verdere verwysing na so 'n gnostiese Evangelie word gemaak deur Pseudo-Tertullianus in sy Adversus Omnes Haereses; 
(.,Valentinus het sy eie Evangelie naas dié van ons") en verder in Tertullanus se De Praescriptione Haereticorum (200 n.C.) waarin hy hom rig teen sekere gnostici (die Valentiniane?) wat II Tim. 2:2 uitlê as verwysing na 'n esoteriese evangelie wat slegs aan ingewydes oorgelewer moet word. Op grond van hierdie skrale berigte het die gissings oor wat die Evangelie van die Waarheid was en wat dit bevat het, begin. Ene JohanNes KREYeNBuHL het tussen 1901 en 1905 'n twee-delige werk van 800 bladsye publiseer waarin hy die stelling gemaak en verdedig het dat die Evangelie van die Waarheid niks anders as ons Evangelie volgens Johannes is nie en dat laasgenoemde bygevolg deur 'n gnosticus geskryf is. Sy boek heet Das Evangelium der Wahrheit. TH. ZAHN, in sy Geschichte des Neutestamentlichen $K a n o n s, B d$. $l$, het minder verbeeldingryk maar waarheidsgetrouer met die skrale gegewens omgegaan en gedink aan die moontlikheid dat ons in die Evangelie van die Waarheid 'n apokriewe mondelinge tradisie moet sien wat deur die Valentiniane op skrif gestel is en as hul besondere Evangelie toegeëien is bo en behalwe die kanonieke Evangelies. Al gevolgtrekking wat A. vON HARNACK, Geschichte der altchristlichen Literatur, B1. 1 daarop waag, is dat IRENAEus die werk self nie onder oë gehad het nie en dat Valentinus dit nie persoolik geskryf het nie.

En daarby het die opinies ten opsigte van die Evangelie van die Waarheid gebly totdat die ontdekking van die geskrif self nou die

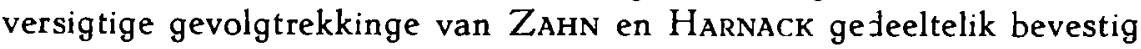
maar KREYENBUHL se 800 bladsye as soveel spekulatiewe nonsens veroordeel. Die outeurskapsvraag bly egter nog steeds oop. Die geskrif self gee geen outeursnaam nie; IRENAEus verklaar slegs dat die volgelinge van Valentinus dit te voorskyn gebring het. Uit die interne getuienis van die geskrif kan slegs die slotwoorde enige aanduiding gee; daaruit blyk namelik dat die outeur in die eerste persoon enkelvoud wou skrywe. Volgens W. C. vaN UNNIK is die styl van die werk deurgaans dieselfde sodat ons nie aan meerdere outeurs kan dink nie. Hy voeg daarby dat die werk wel nog tydens die lewe van $V_{\text {ALENTINuS }}$ geskryf kon gewees het en dat die inhoud daarvan tot so 'n mate ooreenkom met wat ons weet aangaande die leer van Valentinus dat ons kan aanneem dat laasgenoemde self die outeur van ons geskrif was. $V_{A N} U_{N N I K}$ self erken dat die gevolgtrekking nog niks meer as 'n hipotese is nie. Daar kan m.i. inderdaad nog te veel besware ingebring word. Ek wil die vernaamste noem: Apokriewe en pseudepigrafiese geskrifte is altyd onder die naam van een of ander beroemde figuur uit die heilsgeskiedenis geskryf met die doel om dit met apostoliese of skriftuurlike gesag te beklee. Dit werp die vraag up: Op wie sien die "my" van die slotwoorde van die Evangelie van die Waarheid? Daar staan naamlik - ek volg die vertaling wat vaN UNNIK daarvan gee - ..Het past mij, die in de rust geweest ben, niet om nog iets te 
zeggen; maar ik zal in hem zijn om mij ten alle tijde aan den Vader van het $\mathrm{Al}$ te wijden". Die selfaanduiding kan nie op Christus doel nie, want die openingswoorde praat van Hom in die derde persoon as die Woord, die Redder en die Boodskapper van die Vader. Sou dit bedoel wees om te slaan op een van die Apostels of newefigure van die heilsgeskiedenis dan sou die speursin van die tydgenote dit gou genoeg uitgevind het soos in die geval van die Pastor Hermae waarvan die Canon Muratori verklaar dat dit nie vir kerklike voorlesing geskik is nie omdat dit nuperrime, temporibus nostris deur die broer van biskop Pius vervaardig is. Aan die anderkant, as Valentinus dit self geskryf het, sou IrenaEus dit geweet het en nie gewag het om dit te noem nie. Juis hy verklaar egter dat dit ab his (sc. Valentinianis) non olim conscriptum est d.w.s. die Evangelie van die Waarheid is maar onlangs deur hulle (die Valentiniane) geskryf. Voorlopig lyk die verklaring van Puech en Quispel dat dit afkomstig is uit die eerste geslag van dissipels van VALENTINUS die veiligste.

Het die ontdekking van die Evangelie van die Waarheid ook verdere nut vir die teologiese wetenskap? Op hierdie vraag kan reeds op die huidige stand van die ondersoek ' $n$ positiewe antwoord gegee word. Die volle mate van die bydrae van hierdie vonds sal eers gepeil kan word wanneer die verwagte teksuitgawe van PUECH en QuISPEL verskyn het. Maar reeds in hul opstel, Les Ecrits gnostiques du Codex Jung het hierdie twee geleerdes interessante aspekte van die gnostiese teologie tcegelig. So byvoorbeeld blyk nou dat die Valentiniane 'n hele leerstuk opgebou het op die woord, onoma (naam) na aanleiding van Joh. 17:11, waaruit hulle die verhouding van Christus tot God bepaal.

In 'n artikel, Mandaers en Valentinianen, het Quispel daarop gewys dat met behulp van die gegewens uit die Evangelie van die Waarheid, die voorheen onbepaalbare gnostiese naam, Iao, die naam is wat die godheid aan sy seun gegee het en dat dit hierdie "naam" is wat op die ingewydes te ruste kom. Verder, die gnostici het geleer dat die gees van God self in die gevangenskap van die geskapene gekom het. Die verlossingswerk van God in die lewende Christus was 'n daad van selfverlossing. Die sondeval is nie 'n wegbreek van God nie, maar ' $n$ breuk in God self.

Die ontdekking lewer ook 'n bydrae tot die geskiedenis van die kanon. Selfs met die hulp van die Freer-logion. 'n brokkie papyrus uit Joh. 18 uit die eerste helfte van die tweede eeu, was dit nog nie moontlik om weersprekers te oortuig van die relatief vroeë oorsprong van die Evangelie volgens Johannes nie. Nou kan die volgende vasgestel word: As IrenaEus teen 180 n.C. weet dat die Evangelie van die Waarheid ,onlangs", dus kort voor $180 \mathrm{n}$.C. geskryf is, en dit dan veral uit die ondersoek van $V_{A N} U_{N N I K}$ blyk dat die gnostiese evangelie 
die kanonieke Vierde Evangelie reeds geken en verwerk het, dan is dit tog duidelik dat hierdie Evangelie in elk geval voor die jaar 150 n.C. geskryf is. Trouens VAN UNNIK se ondersoek bring talle ontleninge aan ons Nuwe Testament, soos ons dit vandag ken, deur die Evangelie van die Waarheid aan die lig. Die Kanon van die Nuwe Testament moes dan al reeds vorm geneem het toe die Valentiniane hul vyfde evangelie gemaak het.

Uit die Codex Jung in sy geheel en uit die gnostiese Evangelie van die $W$ aarheid in die besonder leer ons van nuuts af hoe 'n moeilike stryd die jong Christendom van die eerste eeue gehad het. TERTulLiANus noem die volgelinge van Valentinus 'n frequentissimum collegium - 'n baie groot menigte. Hippolytus meld dat in die Ooste en die Weste Valentiniaanse skole bestaan en nog in die vierdie eeu, volgens Von HARNACK, het in Egipte en Asië Valentiniaanse gemeentes bestaan. Dit was terselfdertyd die eeue van Christenvervolging deur die owerhede en dit was ook die eeue van die groot leerstellinge twispunte wat gedreig het om die Kerk van binne te skeur.

Wanneer die tekste, na verwagting oor nie al te lange tyd nie, beskikbaar gestel word, kan 'n lewendige en, na ek meen, uiters vrugbare diskussie vir die nutestamentiese wetenskap, die dogmengeskiedenis en die geskiedenis van die godsdienste onder die romeinse ryk, te voorskyn kom. Onderstaande werke waaruit die mededeling hierbo saamgestel is, verteenwoordig die huidige stand van die ondersoek en hou die belofte vir die toekoms in:

1. Puech en Quispel, Op zoek naar het Evangelie der Waarheid. Callenbach, Nijkerk. 1954.

2. W. C. van UnNIK, Het kortgeleden ontdekte „Evangelie der Waarheid" en het Nieuwe Testament. Mededelingen der Koninklijke Akademie van Wetenschappen, Afd. Letterkunde. Amsterdam, 1954.

3. Puech en Quispel, Les Ecrits gnostiques du Codex Jung. art. in Vigiliae Christianae, Jan, en Apr. 1954.

4. G. Quispel, Mandaeërs en Valentinianen. art. in Ned. Theol. Tijdschrift, Febr. 1954.

A. S. Geyser. 